\title{
Government Policy For Urban Poor Community Management In Developing Countries: Case Study - Thailand
}

Apisak Dhiravisit, Khon Kaen University, Thailand

\begin{abstract}
Urban poor community development programs have significantly improved the lives of slum dwellers and increased the quality of life for residents, but the discussion concerning ways to set up the policy for urban community development remains in the conceptual stage. However, in this paper, we will discuss the most important factors for government agencies when considering how to set up the policy. For this research, we collected and analyzed data using both qualitative and quantitative methods. From the data analysis, we discovered that the seven key factors of community-driven housing development and management are: (1) community spiritual life; (2) community savings; (3) community cooperation (4) housing development participation; (5) community organization; (6) operations research; and (7) leadership. The government policies that must be established for the management of urban poor comminuties are: (1) land management policy; (2) decentralization; and (3) land banking policy. Our recommendations in this paper will also be relevant to developing countries similar to Thailand such as Laos, Vietnam, India, Mexico, the Philippines, Cambodia, and South Africa.
\end{abstract}

Keywords: housing development, management, urban poor, government policy

\section{INTRODUCTION}

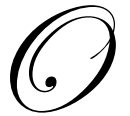

ver the last three decades, population movement from rural areas to urban areas and capital cities has occurred because people in rural areas have faced economic problems and political issues, and the motivation to migrate is that job seekers want to raise their income to achieve a better life (Solinger, 2000). Due to urban population growth, urban development and management are important issues; urban development can be characterized by its complexity, dynamism, and diversity. This characterization is concerned with urban development in a spatial sense, such as the emergence of new areas at the outskirts of the cities and the increasing competition between cities. On the other hand, there is also concern about quality of life, such as security and access to basic utilities and services (Kooiman, 1993). Urban development is set in government policy in every country because many countries still face problems involving how to set policy to assist urban poor communities. Poor families need the most assistance in owning their own homes because of the high cost of renting, which constitutes almost 50\% of their income (Swartz, 2003). However, urban development still faces many problems, such as the five problems of urban poor community development in the U.S.; 1., the policy of the central government cannot serve the urban poor; 2., urban development must focus on economics more than ethics such that the urban poor community (slum) must be the first target to drive out of the city; 3 ., the policy is set by elites such as politicians or businessmen, and they are not concerned with the suggestions of urban poor communities; 4., the decisions of government are not based on good governance; and 5., there is no long-term development plan (O’Connell, 2002)

Southeast Asia is a region composed of several economic leaders surrounded by a few countries where little has changed or improved in the past half century (e.g., Cambodia, Laos, and Myanmar/Burma). Thailand and Vietnam, however, represent relative success stories in this rapidly industrializing part of the developing world, although their paths to success could not, at least until recently, have been more different. Aside from the basic 
similarities of religion, size of population, geographic endowments, and so on, the political economy of the two nations differ in many, if not all, respects (Singh \& Freeman, 2001).

Thailand, and specifically Bangkok, has adopted a generally laissez faire approach to economic development in the last 30 years. As such, the government of Thailand has permitted and, some argue, even encouraged the extreme concentration of the industrial, manufacturing, commercial, and service sectors within the Bangkok Metropolitan Region. While several steps have been taken since the early 1990s to support the deconcentration of economic activities to smaller cities within 100 or so miles of Bangkok, these efforts have had relatively little effect on Bangkok's rate of growth (Carpenter, 2004).

In addition, urban development took place over 20 years. Intensive development came during the third National Economic and Social Development Plan (1972-1976). It was a period during which domestic community development grew rapidly and many communities expanded. The government advocated the growing to development the cities, especially from Bangkok, the heart of Thailand's economy, to other areas in an effort to solve the problem of a crowded population and communities. Thus, urban communities spreading out to local land was one part of the policy to develop the social, economic, and well-being of the population (Panpiemras, 1998).

Thailand's economy was developed through a growth economics strategy, which successfully cultivated the country's growth but caused many problems, such as the bulk of the growth occurring in large urban centers. Thus, growth was unequally distributed, causing people to migrate to large urban centers to find jobs. Migration became a serious problem as Thailand's agrarian economy, population growth, and rising rural unemployment led to urbanization. In response, the government created jobs in rural industries, the idea being that if the people already had jobs in rural areas, they would not move to large urban centers. But this policy failed, and migration continued. Next, the government attempted a strategy that focused on self-reliance. The government tried to reduce people's dependence on others, encouraging them to create jobs for themselves.

The development of housing for the urban poor was given little priority in government policies in Thailand. But in recent years, things have changed considerably as urban housing problems have increased and public agencies at many levels have increasingly acknowledged that the urban poor contribute vitally to the economic wellbeing of the city, and that their lives and settlements should also be developed along with the city they are part of (McGee, 1995; Flanagan, 2002). The city-wide community upgrading process has led to greater empowerment, stronger horizontal networks, and mutual support linkages between poor communities, as well as enhanced spiritual development and greater access to development resources from various sources (Dewilde and Keulenare, 2003). Then, in response to these changing perceptions and changing relationships, the Thai government has implemented the following two important policies for solving the housing problems in Thai cities:

1. The "demand-driven" housing policy: The first housing policy for the poor is "demand-driven" by poor communities themselves, which plan, manage, and implement their own housing and settlement upgrading projects with support from the Community Organizations Development Institute (CODI) under the national Baan Mankong ("Secure House") City-wide Community Upgrading Program. Since it was launched in 1999, this large-scale program has channeled upgrading budgets (through soft housing loans and infrastructure development subsidies) directly to poor community organizations to upgrade and secure the tenure of some 450 poor communities in 200 Thai cities, under the slogan "Cities without Slums" (Boonyabancha, 2004). In December 2006, the government approved a budget of 13.6 billion Baht (US \$389 million) to continue the Baan Mankong Program from 2007-2011, with a target of upgrading 285,000 housing units.

2. The "supply-driven" housing policy: The second housing policy for the poor is "supply-driven" by the National Housing Authority (NHA), which designs, builds, and sells subsidized housing units to poor households who have registered themselves with the national database of low-income people with housing problems. For this Baan EuaArthorn ("We Care Housing") Program, the government has contracted out the building of these housing units (in the form of low- and high-rise blocks of flats, free-standing units, and terraced house types) to private sector developers, and then sells the units on an installment basis to the recipients. 
In Thailand, 8.25 million people, 30 percent of whom are squatters, live in poor-quality housing. The rest rent land but do not have secure contracts. Many communities are under threat of eviction, and only one in five people can afford conventional housing on the open market or through government housing programs. Urban poor community organizations and their networks are the key actors, and they control the funding and the management. They (rather than contractors) also undertake most of the building, which makes funding go much further and brings in their own contributions (Boonyabancha, 2005).

The urban poor communities have also considerably expanded cooperation and proactive partnership between the city's urban poor communities and their local, provincial, and national government institutions, as well as other actors involved in housing development such as local universities, NGOs, temples, and civil society organizations. However, housing for the urban poor is a significant problem, adversely affecting quality of life in the urban community as a whole. Government policy still lacks the ability to solve problems and provide housing subsidies to the urban poor, who must change from urban poor to middle class in urban communities because urban poor people must sell the property to others (Suvant-Mohit, 2004). The exchange of experience and knowledge between communities within the city, which happened throughout the upgrading process through a constant program of meetings and exchange visits, was an important part of the creation of a common understanding about the larger city's development and how the housing problems of the poor fit into that development. Thus, the purpose of this paper is to 1) to study the factors that drive housing development and management and 2) to explore government state policy for housing improvement and urban poor community development.

\section{RESEARCH METHODOLOGY}

In this research, we use both qualitative and quantitative methods. The qualitative method involved spending five years using Participatory Action Research (PAR) methods to gather a great deal of data for this study in close collaboration with the Urban Poor Community Network in nine communities in four regions in Thailand.

In addition, the in-depth interview technique was used to look at all aspects of the urban poor in three communities in Khon Kaen province and one community in Udon Thani province in the Northeast region; one community in Nonthaburi province and one community in Samut Prakan province in the Central region; one community in Chiang Mai province and one community in Pichit province in the North region, and one community in Phuket province in the South region. All data from PAR research methods have been described as a way of creating a democratic dialogue, building collaborative relationships, and enhancing community empowerment.

We also provided 400 questionnaires to 2770 people in nine communities in four regions in Thailand. Then SPSS for Windows (Statistical Package for Social Science) was used to analyze the data using quantitative methods.

\section{RESULTS OF ANALYSIS}

When poor community people were supported in taking the central role in planning and managing the redevelopment of their own housing and environmental conditions, it not only built their confidence and enhanced their skills but it also increased their overall well-being in many ways. However, urban poor communities are often wrongly perceived as having no resources, thus being only able to receive and not to bring anything to the development process. Among the urban poor, an individual household's resource base is an extremely important element in its ability to survive and in its struggle to develop its earning capacity, housing, and tenure security. For this study, data about household resources was collected from 2,770 people in 767 households in the nine case-study communities. $54.5 \%$ of these people were in their active working years (age 16-45 years), while $23.7 \%$ were in their childhood and school-going years (age 1-15 years). Most of these people are natives (70.8\%). The information reveals that the resource base these people draw on can be divided into three aspects: material resources, human resources, and societal/cultural resources.

\section{Material Resources:}

Material resources include a person's savings, income, debts, personal belongings, living conditions, housing assets, and housing tenure assets. The data revealed that with regards to housing tenure assets (Table 1), 
$40.4 \%$ of the people were structure renters on private land and $34.3 \%$ of the people were squatters without any tenure rights on state railways and municipal land. Because most had no legal rights to the land they occupied, there was little motivation for them to invest in housing improvements. Although there had been some buying and selling of informal occupation rights in the None Nong Wat Railway community and some negotiation with the railway authorities, there was no law to support their right to live there. So to a large extent, the poor's land security did not depend on any legalistic land-rights arrangements but more on the people's capacity to negotiate with the land owner or power structures that controlled the land. The data also revealed that with regards to the people's housing assets, $56.0 \%$ lived in houses built of temporary materials, while $47.3 \%$ lived in single-story houses. The most common assets of personal belongings were televisions (89.2\%), motorcycles (71.1\%), and gold ornaments (23.1\%). 51.6\% of the people had some savings, while $48.4 \%$ had some debts. Even though these households did not have tenure security or adequate housing and living conditions, they did have enough income to survive, to save, and to acquire some household assets.

Table 1: Housing tenure assets of nine communities

\begin{tabular}{|c|c|c|}
\hline \multirow{2}{*}{ Housing Tenure Assets } & \multicolumn{2}{|c|}{ Total } \\
\cline { 2 - 3 } & $\begin{array}{c}\text { Number of } \\
\text { People }\end{array}$ & Percent \\
\hline Rent & 1,120 & 40.4 \\
\hline Homeowner & 460 & 16.6 \\
\hline Squatter & 950 & 34.3 \\
\hline Etc. & 240 & 7.7 \\
\hline Total & $\mathbf{2 , 7 7 0}$ & $\mathbf{1 0 0 . 0}$ \\
\hline
\end{tabular}

\section{Human Resources:}

Human resources include a person's job skills and occupation, education, immediate and extended family assets, community and neighbor support systems, and physical health and abilities. Lee and Hsin (2004) suggested that human capital must face a lot of problems; however, if they have opportunities to train and gain more knowledge, it will raise up the overall skill and quality of the population.

The data revealed that people considered their jobs as their most important resource. Among the majority of the jobs people had in the informal sector, there were general employment $21.2 \%$ and $22.7 \%$, respectively and the obvious changes occurred between 2005 and 2006 (Table 2) job seeking 32.8\% and 19.7\%.

The second most important human resource people identified was their number of children. Most households in the case study communities had between 2 and 3 children (48.7\%). The greatest proportion of children were those of pre-school and school age (25.5\%). The next most important human resource was identified as education, with $45.6 \%$ of the surveyed people having finished only their primary level of education. The last human resource was identified as physical health. 50.8\% of the surveyed people were not treated during their most recent illness, and this illustrates the vulnerability of the poor due to their insufficient access to health care, and how easily a lack of affordable health care can compromise this important human resource of physical health. 
Table 2: Kinds of occupations between July 2005-2006

\begin{tabular}{|c|c|c|}
\hline \multirow{2}{*}{$\begin{array}{l}\text { The occupations of } \\
\text { community residents }\end{array}$} & July 2006 & July 2005 \\
\hline & $\begin{array}{c}\text { Percentage of total surveyed } \\
\text { workers }\end{array}$ & $\begin{array}{c}\text { Percentage of total surveyed } \\
\text { workers }\end{array}$ \\
\hline Agriculture & 1.8 & 2.1 \\
\hline Housekeeping & 5.6 & 4.4 \\
\hline General employment & 22.7 & 21.2 \\
\hline Construction & 2.5 & 1.7 \\
\hline Skill (artificial flowers) & 0.5 & 0.5 \\
\hline Selling at market & 2.7 & 2.5 \\
\hline Selling at bus terminal & 0.4 & 0.4 \\
\hline Food vendors & 1.7 & 1.7 \\
\hline Selling products at stall & 2.5 & 2.5 \\
\hline Community shop & 3.0 & 2.0 \\
\hline Recycling & 1.7 & 1.3 \\
\hline Mini-bus driving & 0.2 & 0.2 \\
\hline Tricycle driving & 0.7 & 0.8 \\
\hline Motor-tricycle driving & 0.2 & 0.3 \\
\hline Tuk-tuk driving & 0.4 & 0.5 \\
\hline Students & 18.5 & 14.1 \\
\hline Sales persons at department stores & 1.1 & 0.9 \\
\hline Security guards & 0.9 & 0.7 \\
\hline Pre-school children & 7.0 & 5.1 \\
\hline Disabled & 0.2 & 0.1 \\
\hline Job seeking & 19.7 & 32.8 \\
\hline Doing nothing & 5.8 & 4.3 \\
\hline Total & 100.0 & 100.0 \\
\hline
\end{tabular}

\section{Societal/Cultural Resources:}

Societal and cultural resources include the community as a social unit, the relationships of friendship and mutual support that exist within the community, the social organizations that exist in the community, the religious and cultural events that happen in the community, and the access to media (like television, radio, newspaper and phone) in the community. $92.1 \%$ of people had or watched television, the most important media outlet, while only $54.9 \%$ read newspapers. The data revealed that relationships within families were strained by husband-wife conflicts $(45.8 \%)$, domestic violence (17.3\%), and conflicts between parents and children (30.0\%). One in three households did not belong to any social organizations in the community. Many people also identified luck as an important social asset, with $36.8 \%$ of people having played and won something in the underground or state lottery at some point, and another $10.5 \%$ having gambled at cards, football, or horseracing.

Satisfaction with their present way of life among the community members can also be considered a kind of social asset and dissatisfaction with their lives as a serious problem. The data revealed four different aspects of how people perceived shortcomings in their own lives:

- $\quad$ The life they dreamed about: $42.6 \%$ felt their lives did not match their dreams, whereas $29.6 \%$ were satisfied with their present lives.

- $\quad$ Their living conditions: $36.8 \%$ were not happy with their living conditions.

- Their capacity to acquire important material things: $41.5 \%$ felt they did not have the important material things they wanted.

- $\quad$ Their desire to return to a past time: $45 \%$ felt that turning back the clock to some mythical Thai past would not change anything. 
In the nine case-study communities, differences in ethnic and cultural bases were very few because over $70.0 \%$ of the residents are natives of the region. There are also very few differences between the communities in economic terms; most residents are self-employed in the informal sector or have low-paying jobs with informal or formal sector employers, and most have the problem of uncertain income. Residents in all nine communities also have in common a lack of any secure legal housing or land rights. Another common thread in the nine communities is a high percentage of households with televisions that are almost always on, bringing in new perceptions and new aspirations that come from affluent urban centers (in Thailand and from overseas) and promote a capitalist and materialist way of life and way of looking at the world.

\section{COMMUNITY-DRIVEN HOUSING DEVELOPMENT AND MANAGEMENT}

The housing development process for the urban poor described in the diagram below gives importance to the community with regard to the seven key factors for management to drive the process of developing housing, linking families within the community and with other communities, and exchanging knowledge and experiences. All these activities involve the pursuit of greater well-being (Chambers, 2004). The cooperative process brings about the synergistic development of communities in seven ways (Fig. 1). In the following section, this is used to analyze the various aspects of the housing development and management process, and this common understanding represents seven key factors to become guidelines for sustainable housing development for the urban poor as follows:

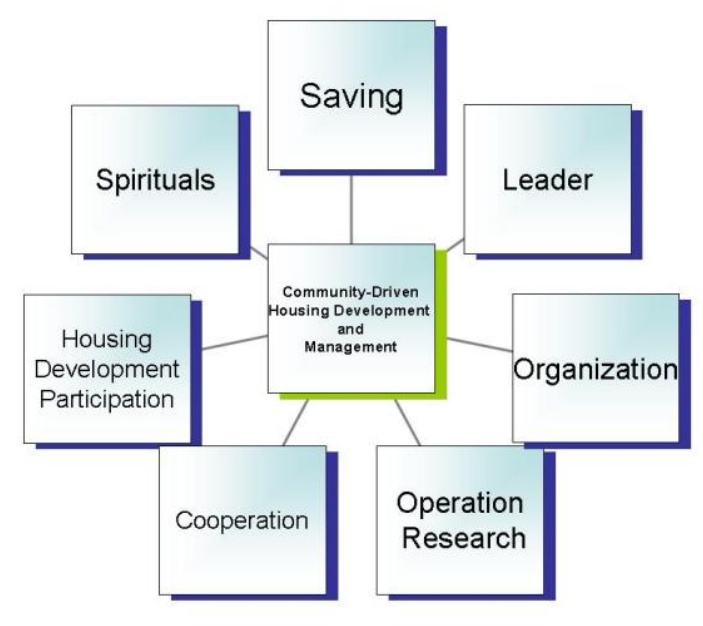

Figure 1: Seven key factors of community-driven housing development and management

\section{A community's spiritual life:}

A community's spiritual life is important as a means for creating cooperation and mutual support in times of gladness and trouble - all things that lead community members out of a more self-centered way of living and towards a more common interest in the community as a whole. From the implementation of the poor's housing development, these poor people were found to be proud of housing built by themselves and from their own savings - that was a dream come true for them. Some members deemed it as starting a new life; some with newborn babies named them after the community's name "New Sun" or new life.

\section{Community savings:}

Urban communities must have an active collective savings process that includes most members of the community. If people can manage finances collectively, they have the power and independence to do anything (Boonyabancha, 2005). Collective saving is a way for poor communities to organize themselves, build their own 
financial resources, and learn to manage money jointly to resolve needs and problems they identify themselves. Collective saving is an activity that brings poor people within a community together and creates a sustainable model for self-development in which communities plan, implement, and finance the resolution of their own needs. Community savings groups in Thailand are also increasingly using a portion of the interest earned on loans to members to finance their own community-based welfare programs. The patterns of earning and spending are different in each community, so different communities may adopt daily, weekly, or monthly savings systems (or a combination of all three), according to what is most convenient for the earning patterns of their members. Communities are also free to set their own criteria for getting loans for various purposes and setting the terms of interest and repayment.

For example, the people developed savings guidelines and decided to allocate most of their loans to members for the purpose of paying off high-interest debts from informal money-lenders, since indebtedness was one of the most serious problems among members. The community savings group also gave loans for occupational development of households earning their living by collecting recyclable waste. These trash collectors had previously used a three-wheeled push cart to go around the city collecting recyclable materials. Loans from the savings group allowed these informal recyclers to make a down payment on a motorcycle-powered cart, which enabled them to collect more garbage and cover a larger area, at a greater distance from home in several rounds per day, thus increasing their daily income.

\section{Community cooperative:}

Communities are required to form a cooperative in order to access the upgrading subsidies and soft housing loans the program offers. The cooperative gives informal communities the legal status they need to buy alternative land collectively or else to negotiate a formal long-term community lease to the land they already occupy. These cooperatives have their own systems of internal checks and balances, as well as external checks and balances provided by the city-wide network of poor communities.

\section{Housing development participation:}

The central participation of community members in each step of the housing and settlement upgrading process is common to all communities, and in all of the case-study communities in this study, beginning with collecting data about the original settlement and its occupants, to designing affordable house models and new community layouts, to setting the community's long-term development goals after the housing project is finished. All these aspects of the community's comprehensive development are people-driven and ultimately lead to longterm, sustainable well-being for the community members.

\section{Community organization:}

When housing development is driven by poor community organizations themselves, the organization must happen at two levels, both with clear functions and clear responsibilities:

- Organization of members within the community to plan and implement the upgrading projects inside the community.

- Organization of poor communities within the city and the region into networks, which then have the numbers and the collective capacity to link with other outside organizations.

This pairing of community organizations at two levels is based on the understanding of potentials and limitations of each group. The larger groupings of poor communities create a greater space for individual communities to experiment, learn, share, and participate in the larger urban development process with dignity, where the smaller groupings within a given community create space for individual people and households to participate in the redevelopment of their own settlement. In the case of the Dynamo saw-mill community, which decided to relocate and build new housing on land they purchased collectively, the community developed a management system in which each row of houses in the new development had a leader and an assistant leader, who would represent the households in their row for purposes of supervising the construction. 


\section{Operations research:}

"Operations research" in the context of these case study communities includes the participatory surveying of the community, identifying of its problems and potential strengths, and the creation of an ongoing community database and set of potential solutions to the problems that people identify. The main principle of all this "operations research" is that communities study their own problems and conditions, set their own priorities for finding solutions to them, and maintain their own information about their settlement.

\section{Leadership:}

Leadership within the community and within the city-wide network of poor communities is a very important factor in how poor communities are able to set their housing development goals and achieve them.

\section{CONCLUSION}

Urban poor community management is one issue that government should be concerned with for country development; government must not only listen to the people but also involve them actively in all stages of the policy process. The philosophy is that, by providing such competence, the residents are supposed to be capable of managing their own lives and undertake the necessary actions for improvement (Andersen, 2001). From our study, we found three policies for setting up the management of urban poor communities:

1) Land management policy for urban poor communities. This policy requires unused land and no private owner to allot with cheap housing and low prices for urban poor communities; in addition, government agencies must develop environmental and public infrastructure to support new urban communities.

2) Decentralization. The central government should decentralize the management and give authority to local government under cooperation with any agencies in any department of all ministries in addition to the private sector (Public-Private Partnership: PPP). Such a program will raise up the all aspects of competency management, facilitate on-time problem-solving, and be based on the requirements of urban poor communities.

3) Land banking policy. The government land development agencies or departments should study and make a future plan for land development, such as studying the question of which area should be developed in the near future, and then, when the study has confirmed the suitability of the location, government agencies and/or local government should buy that land when it is still at a low price.

\section{ACKNOWLEDGEMENTS}

This work was supported by the Faculty of Humanities and Social Science at Khon Kaen University, Thailand, and we also acknowledge with appreciation Dr.Thongphon Promsaka Na Sakolnakorn for the helpful suggestions and comments on this research article.

\section{REFERENCES}

1. Andersen, H.T. 2001. The new urban politics of Europe: the areabased approach to regeneration policy. In Governing European Cities, Social fragmentation, Social Exclusion and Urban Governance, (eds) H T

2. $\quad$ Andersen and R V Kempen., pp 233-253. Ashgate Publishing Limited, Burlington.

3. Boonyabancha, S. 2005. Baan Mankong: going to scale with "slum" and squatter upgrading in Thailand.

4. Environment \& Urbanization, 17(1), 21-46.

5. Boonyabancha, S. 2004. A Decade of Change: From The Urban Community. Development Office to the

6. Community Organization Development Institute in Thailand. (pgs. 25 - 49).

7. Chambers, R.2004. Ideals for development: reflecting forwards. Brighton UK: XPS Limited.

8. Carpenter, J.P., Amrita G. Daniere, A.G. and Takahashi, L.M. 2004. Cooperation, trust, and social capital in Southeast Asian urban slums. Journal of Economic Behavior \& Organization, 55, 533-551 
9. Chui, E 2001. Doomed Elderly People in a Booming City: Urban Redevelopment and Housing Problems of

10. Elderly People in Hong Kong. Housing, Theory and Society, 18, 158-166.

11. De wilde, C and Keulenare,F.D.2003. Housing and Poverty: 'The Missing Link'. European Journal of Housing Policy, 3(2), 127-153.

12. Dekker, K. \& Kempan, R.V. (2004). Urban governance within the Big Cities Policy. Cities, 21 (2), $109-$ 117.

13. Flanagan, W.G. 2002. Urban Sociology Image and Structure. $4^{\text {th }}$ ed. Boston: A Pearson Education Company.

14. Hashimoto, K. 2002. New Urban Sociology in Japan: The Changing Debates. Urban and Regional Research.

15. Kooiman, J (ed.) 1993. Modern Governance. Sage, London.

16. Lee, Joseph S. and Hsin, Ping-Lung. 2004. Employee Training and Human Capital in Taiwan, Journal of World Business. 39, 362-376.

17. McGee, T.G. \& Robinson, I.M. (1995). The Mega-Urban Regions of Southeast Asia. Vancouver: UBC Press

18. Munk, A. 2002. Social Partnership in Distressed Neighborhoods: The Danish Case. European Journal of Housing Policy. 2(3), 223-244.

19. O'Connell, G. E. 2002. Problems with the US program approach to urban housing: can Europe lead America to a policy solution in 2002 and beyond. European Journal of Housing Policy, 2(3), 293-307.

20. Panpiemras, K. 1988. Rural industrialization in Thailand. National Economic and Social Development Board, Bangkok: P Press.

21. Solinger. D. J. 2000. Internal migration in China. World Development Journal, 27(2), $463-474$.

22. Singh, D., Freeman, N. 2001. Regional outlook: Southeast Asia 2001-2002. Institute of Southeast Asian Studies, Singapore.

23. Suvan-Mohit, R. 2004. Security of Tunure and the Way forward: The Case of Samakee Pattana Bangkok. Habitat International. 28 (1), 301-316.

24. Swartz, R.J. 2003. The Housing Situation of Low-income Families in Milwauke. Journal of Policy Development and Research. 6 (2), 159-197. 
NOTES 